\title{
Tolerance to Desiccation of Diospyros inconstans Jacq. (Ebenaceae) Seeds at Different Maturity Stages
}

\author{
Edvânia da Silva Carvalho ${ }^{1}$ \\ Manuela Oliveira de Souza ${ }^{1}$ (]) \\ Josival Santos Souza ${ }^{1}$ (]) \\ Darlene Pereira da Silva ${ }^{1}$ (]) \\ Jiovana Pereira Amorim Santos ${ }^{1}$ \\ Andrea Vita Reis Mendonça ${ }^{1}$ (1)
}

${ }^{1}$ Universidade Federal do Recôncavo da Bahia (UFBA), Cruz das Almas, BA, Brasil

\begin{abstract}
Classifying seeds in terms of desiccation tolerance is the first step in determining the potential and most appropriate conditions for storage. This study aimed to characterize the tolerance to desiccation of Diospyros inconstans seeds from fruits at different maturity stages. Germination tests were performed in a $3 \mathrm{x} 6$ factorial scheme, with seeds from fruits at three maturity stages (unripe, intermediate and ripe) and six moisture contents (initial, 20\%, 15\%, $10 \%, 5 \%$ and $2.5 \%$ ). Accumulated germination was analyzed by the nonlinear models Gompertz and Logistic. The percentages of normal seedlings and unviable seeds were subjected to analyses of variance and regression. Diospyros inconstans seeds are tolerant to desiccation. The tolerance is higher in seeds from fruit with intermediate maturation than unripe and ripe fruits.
\end{abstract}

Keywords: 'fruta de jacu', germination, moisture content.

\section{INTRODUCTION}

Tolerance to desiccation consists in the capacity of some organisms to survive under extreme reduction in their moisture content, without undergoing lethal damage (Leprince \& Buitink, 2010). Changes in cell membrane structure, accumulation of non-reducing sugars such as sucrose and oligosaccharides, and LEA protein synthesis are some of the physiological and biochemical modifications that promote desiccation tolerance in seeds (Black \& Pritchard, 2002; Finch-Savage, 2003; MarcosFilho, 2015; Bewley \& Nonogaki, 2017; Colville, 2017).

The degree of tolerance to desiccation and to storage at low temperatures is the basis for the classification of seeds into the orthodox (tolerant of desiccation and storage at negative temperatures), intermediate (partially desiccant tolerant and sensitive to storage at negative temperatures) and recalcitrant categories (intolerant to desiccation and storage at negative temperatures) (Roberts, 1973; Ellis et al., 1990) and determines the potential and most appropriate conditions for storage.
Such information is of great interest for the management of ex situ conservation of plant species (Hong \& Ellis, 1996).

Desiccation-tolerant seeds do not exhibit these characteristics at all stages of development (Ellis \& Hong, 1992). When collected unripe or after maturity, these seeds may be sensitive to damage caused by desiccation (Hong \& Ellis, 1996; Berjak \& Pammenter, 2008), so the most indicated time to collect these seeds is when physiological maturity and tolerance are reached together (Ellis et al., 1987).

There is little information in the literature on desiccation tolerance of seeds of forest species, such as Diospyros inconstans, popularly known in Portuguese as 'fruta de jacu' or 'marmelinho'. This native species of shrubby to arboreal habit has wide distribution in the Brazilian territory, being found in the plant formations of almost all biomes (Wallnofer, 2015; Flora do Brasil, 2020). It has ornamental potential for use in urban forestry and is recommended for the composition of heterogeneous reforestation, due to the attractiveness of its fruits to the fauna (Cipriani et al., 2017). 
In view of the above, the present study was carried out to characterize the tolerance to desiccation of D. inconstans seeds at different maturity stages.

\section{MATERIAL AND METHODS}

The experiment was conducted at the Laboratory of Ecology and Forest Restoration, of the Forestry Engineering sector, of the Federal University of Recôncavo da Bahia, on the campus of Cruz das Almas, Bahia, Brazil.

Diospyros inconstans fruits at different maturity stages (Figure 1) were collected from 17 mother plants, in a region of pasture of the Environmental Protection Area of the Pedra do Cavalo pond, in the district of Ipuaçú, Feira de Santana, Bahia, Brazil (12²1'38.0”S and 39 $\left.02^{\prime} 26.0^{\prime \prime} \mathrm{W}\right)$ in November 2018.

\begin{tabular}{|llcr|}
\hline Fruits & Fruit color & Fruit maturity \\
\hline GREENISH-BROWN & GREEN & INTERMEDIATE \\
\hline
\end{tabular}

Figure 1. Visual aspect of fruits and seeds of Diospyros inconstans Jacq. at different maturity stages

The climate of the region is Asa, megathermal with rainy season in winter and dry season in summer (Santos et al., 2018). Average annual rainfall and temperature are $720.7 \mathrm{~mm}$ and $25.2^{\circ} \mathrm{C}$, respectively (Santos et al., 2018).

After collection, the fruits were taken to the laboratory and visually separated based on epicarp color into three maturity stages (Figure 1). The seeds were manually extracted from the fruits, washed in running water and arranged on trays for superficial drying for three days at room temperature (average of $25^{\circ} \mathrm{C}$ ), before installing the experiment. The moisture content of the seeds freshly collected and after surface drying (initial moisture content the experiment) was determined by the oven method at $105 \pm 2{ }^{\circ} \mathrm{C}$ for 24 hours (Brasil, 2009).

Tolerance to desiccation was evaluated according to the methodology proposed by Hong \& Ellis (1996). From the moisture content (\%) and initial mass ( $\mathrm{g}$ ) of the seeds, the final mass ( $\mathrm{g}$ ) corresponding to the moisture contents of $20 \%, 15 \%, 10 \%, 5 \%$ and $2.5 \%$ was estimated for each maturity condition by the formula: mass of seed $(\mathrm{g})$ at DMC\% $=[(100-$ initial MC\%) $\mathrm{x}$ initial seed mass (g) $] /$
(100 - DMC\%), which DMC\% is desired moisture content. To obtain these moisture contents, the seeds were dried with blue silica gel $(1-3 \mathrm{~mm})$ in $700-\mathrm{cm} 3$ polystyrene boxes sealed with PVC film, at $20^{\circ} \mathrm{C} \pm 2{ }^{\circ} \mathrm{C}$ (adapted from Hong \& Ellis, 1996). In the first 24 hours of drying, the seeds were weighed every three hours and, after this period, every day, until they reached the target mass, and then subjected to the germination test.

In the germination tests, the seeds were arranged in germitest paper rolls, moistened with distilled water in the proportion of 2.5 times the weight $(\mathrm{g})$ of the dry paper (Brasil, 2009). The rolls were placed in transparent plastic bags and put in a B.O.D. germination chamber with constant temperature of $25^{\circ} \mathrm{C}$ and photoperiod of 12 hours of light (Cipriani et al., 2017). The evaluations were performed daily, with counting of germinated seeds (minimum radicle length of $2 \mathrm{~mm}$ ), dead seeds, hard seeds, normal seedlings and abnormal seedlings (Brasil, 2009) for 90 days.

The experimental design was completely randomized, in a $3 \times 6$ factorial scheme, with three maturity stages 
(unripe, intermediate and ripe) and six moisture contents (initial, 20\%, 15\%, 10\%, 5\% and 2.5\%). Each treatment comprised four replicates of 25 seeds.

At the end of the experiment, the viability of hard seeds was confirmed by the $0.5 \%$ tetrazolium test, with seed exposure time of two hours, at a temperature of $30^{\circ} \mathrm{C}$ (Silva et al., 2016).

Germination curves were analyzed by fitting the nonlinear models Gompertz: $\mathrm{Y}=\Theta_{\mathrm{a}}{ }^{*} \exp \left[-\exp \left(\Theta_{\mathrm{b}}{ }^{*}\left(\mathrm{x}-\Theta_{\mathrm{c}}\right)\right)\right]$ (Souza et al., 2014) and Logistic: $\left.\mathrm{Y}=\Theta_{\mathrm{a}} / 1+\exp \left(-\left(\mathrm{x}-\Theta_{\mathrm{i}}\right) / \Theta_{\mathrm{s}}\right)\right)($ Zeviani et al., 2013), where $\mathrm{Y}=$ germination accumulated in time $\mathrm{t} ; \Theta_{\mathrm{a}}=$ asymptotic value, representing the maximum percentage of accumulated germination; $\exp =$ base of the Napierian logarithm; $\mathrm{x}=$ value of the independent variable (time required for germination to occur), given in days; $\Theta_{b}=$ relative growth at the inflection point; $\Theta_{c}=$ time required for $37 \%$ of the seeds to germinate; $\Theta_{i}=$ time required for $50 \%$ of the seeds to germinate; $\Theta_{s}=$ parameter related to the function rate, without biological interpretation.

The parameters of the models were estimated by the method of least squares and Gauss Newton using the nls function in $\mathrm{R}$ software version 3.1.3 (R Development Core Team, 2019). The most adequate model to describe the germination curves was selected based on the Akaike information criterion (AIC) (Akaike, 1974) and Bayesian information criterion (BIC) (Schwarz, 1978), and the best fit equations were those with the lowest values of these criteria (Emiliano et al., 2014).

Data relative to the percentage of normal seedlings and unviable seeds (dead seeds + abnormal seedlings) were subjected to analyses of variance and regression in R software version 3.1.3 (R Development Core Team, 2019).

\section{RESULTS AND DISCUSSION}

The moisture content of the freshly collected seeds was $45.2 \%$ in the seeds of unripe fruits, $46.3 \%$ in the seeds of intermediate fruits and $41 \%$ in the seeds of ripe fruits. This moisture content is similar to that obtained for the seeds of ripe fruits of the species Diospyros brasiliensis (43.3\%) e Diospyros hispida (49.5\%) in the study by Mayrink et al. (2016).

The drying time for D. inconstans seeds is shown in Table 1. Unripe seeds took the longest time to reach the moisture content of $2.5 \%$ ( 1,248 hours). Intermediate seeds were the slowest ones to reach moisture contents of $20 \%$ (63 hours), 15\% (97 hours) and 10\% (352 hours). The drying of ripe seeds was the fastest for all final moisture contents (Table 1).

Table 1. Drying time (hours) for seeds from unripe, intermediate and ripe fruits of Diospyros inconstans Jacq. to reach the target moisture contents.

\begin{tabular}{|c|c|c|c|}
\hline Maturity & $\begin{array}{c}\text { Initial moisture content } \\
(\%)\end{array}$ & $\begin{array}{c}\text { Final moisture content } \\
(\%)\end{array}$ & $\begin{array}{l}\text { Time } \\
\text { (hours) }\end{array}$ \\
\hline \multirow{5}{*}{ Unripe } & \multirow{5}{*}{25.8} & 20 & 23 \\
\hline & & 15 & 24 \\
\hline & & 10 & 262 \\
\hline & & 5 & 743 \\
\hline & & 2.5 & 1.248 \\
\hline \multirow{5}{*}{ Intermediate } & \multirow{5}{*}{32.8} & 20 & 63 \\
\hline & & 15 & 93 \\
\hline & & 10 & 35 \\
\hline & & 5 & 744 \\
\hline & & 2.5 & 784 \\
\hline \multirow{5}{*}{ Ripe } & \multirow{5}{*}{20.9} & 20 & 1 \\
\hline & & 15 & 18 \\
\hline & & 10 & 64 \\
\hline & & 5 & 262 \\
\hline & & 2.5 & 352 \\
\hline
\end{tabular}


The estimated parameters and selection criteria of the Gompertz and Logistic models for the germination of $D$. inconstans seeds are presented in Table 2. In general, the Gompertz model resulted in better fits for all maturity stages tested.

The accumulated germination $\left(\Theta_{\mathrm{a}}\right)$ was above $90 \%$ for the seeds at the three maturity stages evaluated, regardless of the moisture content, except for unripe seeds at $2.5 \%$, for which the estimated accumulated germination was 85\% (Table 2). Although D. inconstans seeds are dispersed with high moisture content, a common characteristic in recalcitrant species that do not tolerate desiccation, the maintenance of a high percentage of germination in seeds that had their moisture content reduced to $5 \%$ or less, demonstrates the capacity of tolerance to desiccation and indicates intermediate or orthodox behavior regarding storage (Hong \& Ellis, 1996). Seeds of Diospyros brasiliensis and Diospyros hispida, dispersed with moisture content above $40 \%$, showed $60 \%$ and $63 \%$ germination when desiccated to $5 \%$ moisture content and were classified as intermediate, after storage for three months at $-18{ }^{\circ} \mathrm{C}$ (Mayrinck et al., 2016). Similar behavior was observed by Pritchard et al. (2004) and Daws et al. (2006) for several tropical forest species and led these authors to conclude that seed moisture content at shedding is not a good predictor of desiccation tolerance.

Seed desiccation tolerance is commonly found in pioneer species that grow in seasonal and/or arid environments, while sensitive to desiccation seeds are more common in non-pioneer species and humid environments and little seasonal (Tweldde, 2003). Diospyros inconstans is a demanding light climax species (Callegaro et al., 2014) with predominant occurrence in seasonally dry tropical forests (Wallnofer, 2015). Despite being a species classified as climax, in the region of Feira de Santana where the seeds of the present study were collected, this species occurs in clearings in pasture areas and behaves like a pioneer. In this region, precipitation is seasonal and the temperature varies throughout the year (Santos et al., 2018). From an ecological point of view, desiccation tolerance represents a defense strategy to delay germination until conditions are suitable for efficient seedling establishment (Colville, 2017). Thus, the presence of tolerance to desiccation in seeds of this population may contribute to keeping the seeds viable in the soil bank during the dry season, until the arrival of the rainy season and milder temperatures.

Seeds subjected to artificial drying tolerate desiccation as long as they have already acquired this characteristic in the field (Ellis et al., 1987; Kerbauy, 2008). For many species, tolerance to desiccation is acquired in the middle of the maturation phase (Hong \& Ellis, 1992; Buitink \& Leprince, 2018). This condition prepares the seed to survive the rapid reduction of moisture content during drying. With the reduction in moisture content, the seed becomes quiescent and tolerant to various environmental stresses, including high temperature and low atmospheric vapor pressure (Buitink \& Leprince, 2018). Thus, the tolerance to desiccation represents a survival strategy to delay germination until the conditions are adequate for the efficient establishment of seedlings (Barbedo \& Marcos-Filho, 1998; Angelovicci, 2010).

Seed germination speed is one of the criteria associated with the vigor of seed lots (Krzyanoswski \& Neto, 2001), lots that germinate faster are considered more vigorous. The parameter $\Theta_{c}$ of the Gompertz model is one of the tools that can be used to compare the physiological potential between seed lots (Souza et al., 2014). According to the model, lower values of this parameter indicate that the accumulated germination of $37 \%$ will be reached faster and, consequently, greater the vigor of the seed lot.

In unripe seeds, the time for germination to reach $37 \%$ ranged from 14.4 to 18.1 days among the different levels of drying, with the shortest time observed for seeds desiccated to 5\% (Table 2). For seeds from intermediate fruits, the time to reach this same germination percentage was shorter and ranged from 13.1 to 15.9 , with the shortest time reached at $2.5 \%$ moisture content (Table 2). For seeds from ripe fruits, the time varied from 14.5 and 16.9 days, and the shortest time was also observed at $2.5 \%$ (Table 2). These results suggest that seeds from intermediate fruit were more vigorous.

The percentage of normal seedlings was influenced by the desiccation in seeds from unripe fruits. At the highest moisture contents, the percentage of normal seedlings was higher $(\mathrm{p}$-value $=0.022)$ and, consequently, the percentage of unviable seeds decreased $(\mathrm{p}$-value $=0.013)$ (Figure 2$)$. 


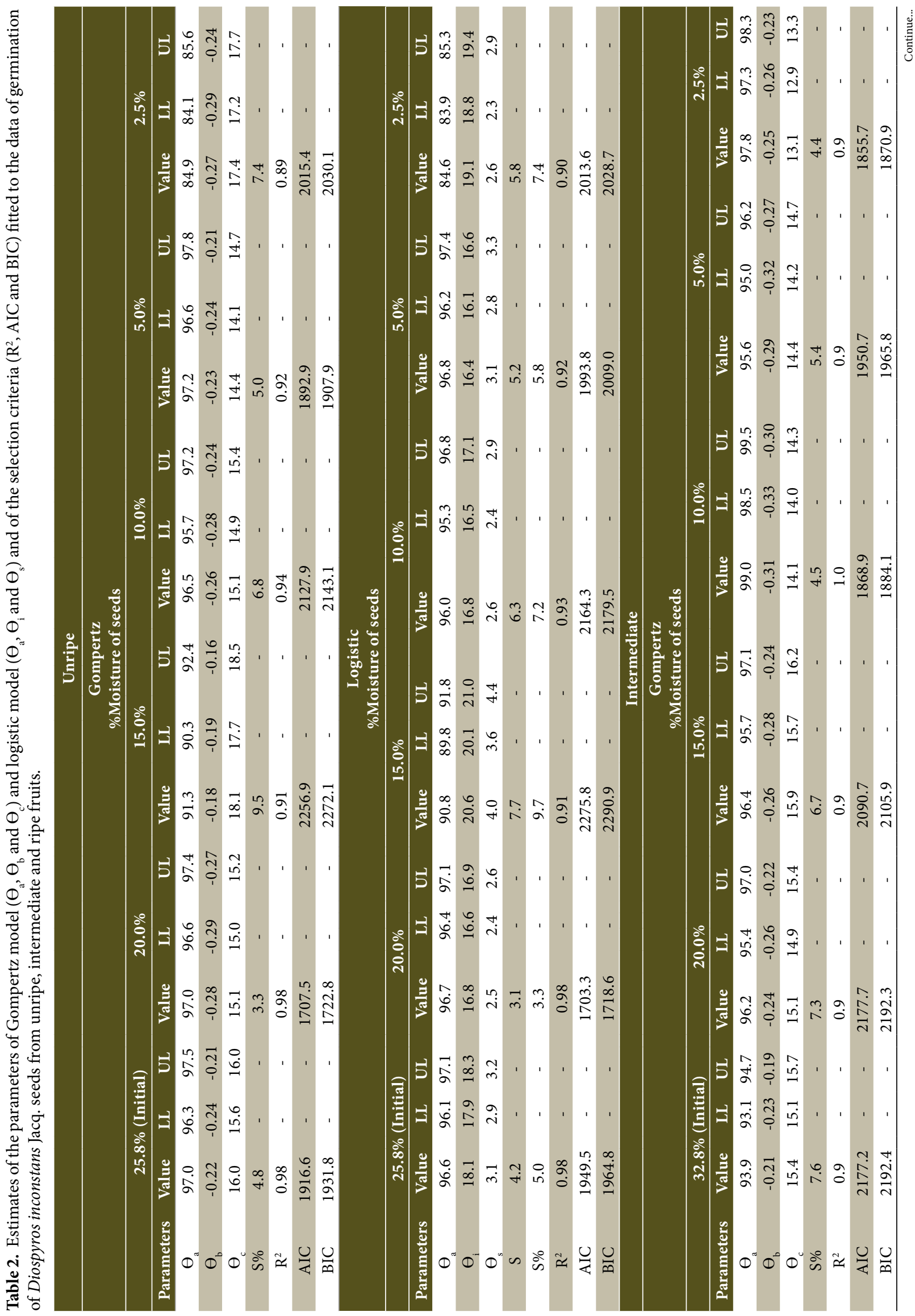




\section{䁌:

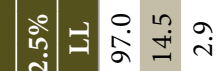

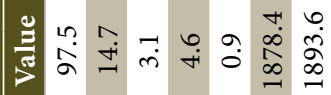

S)

in

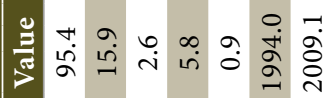

Sڤ̆

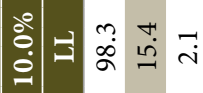

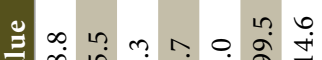

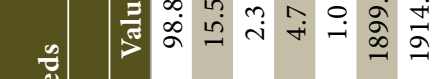

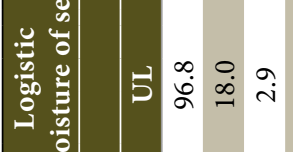

i̊n

光

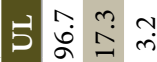

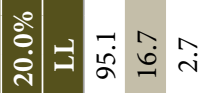

光

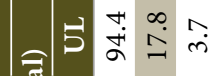

氖

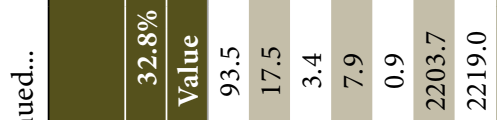

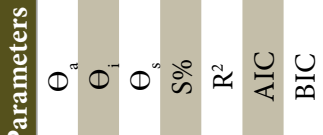

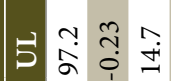

กิ

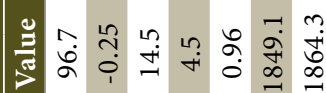

S

ம்:

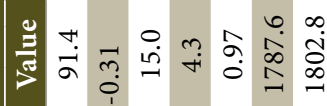

S)

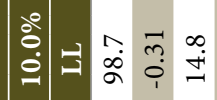

当

S

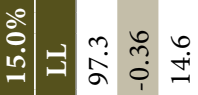

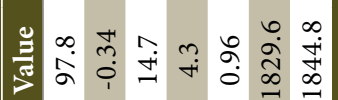

불

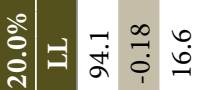

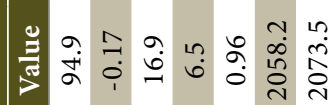

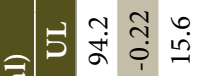

㓂

E

齐

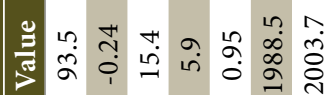

क्षे

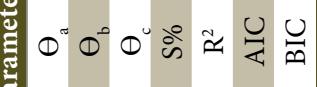

S

iें

ง

当

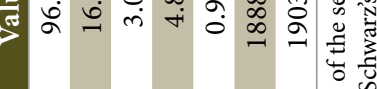

इ

iั

○े

웅

当

节 产

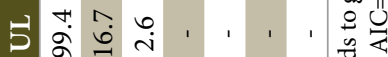

运

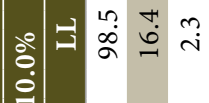

壱 青

원

के

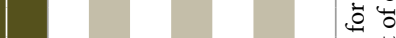

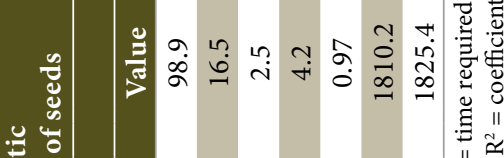

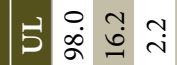

$\circ$ 움

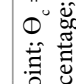

$\stackrel{10}{1}$

先 岤

Sڤ̆

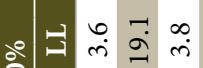

สิ่

深

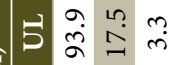

节

政

벅

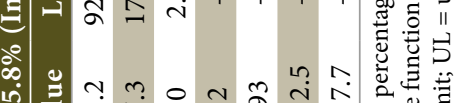

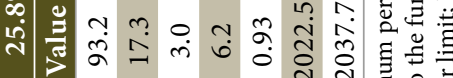

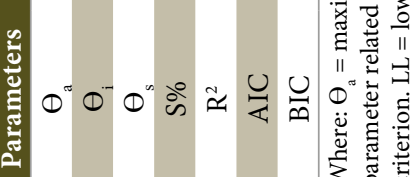




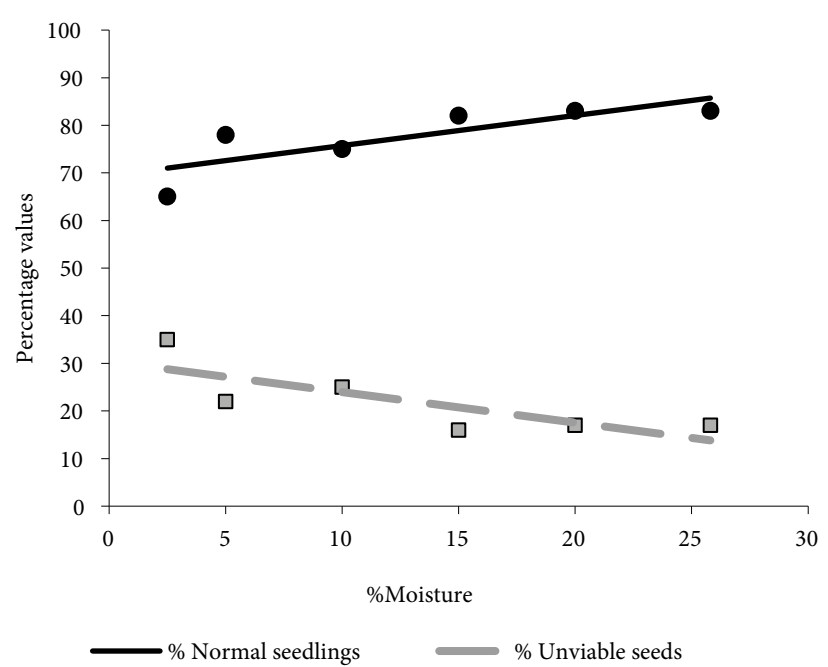

Figure 2. Percentage of normal seedlings $(\% \mathrm{NS}=0.6314 \mathrm{x}+69.427$; $\left.\mathrm{R}^{2}=0.66\right)$ and unviable seeds (\%US $=-0.4688 \mathrm{x}+27.028 ; \mathrm{R}^{2}=0.63$ ) as a function the moisture content in seeds from unripe fruits of Diospyros inconstans Jacq. Where: $\mathrm{R}^{2}=$ coefficient of determination.

For seeds from fruits at intermediate maturity stage, the percentage of normal seedlings ( $p$-value $=0.11$ ) and the percentage of unviable seeds $(p$-value $=0.10$ ) were not influenced by desiccation. The average percentage of normal seedling was around $80 \%$ for all moisture contents tested.

For seeds from ripe fruits, the percentage of normal seedlings $(\mathrm{p}$-value $=0.02)$ and the percentage of unviable seeds ( $p$-value $=0.02)$ responded to the moisture content of the seeds, according to fourth-degree equations (Figure 3). The highest percentage of normal seedlings occurred at the moisture contents $11 \%$. At moisture content of 5\%, the lowest percentage of normal seedlings was obtained (72.6).

The ability to form normal seedlings is one of the indicators of seed physiological maturity (Ellis et al., 1987). Therefore, knowing that tolerance to desiccation is gradually acquired throughout development, the reduction in the ability of unripe seeds to form normal seedlings when desiccated to $10 \%$ indicates that at this stage, the seeds have not fully reached desiccation tolerance. Several studies report that seeds that are tolerant to desiccation, when collected early, are sensitive to this condition (Ellis et al., 1987; Ellis et al., 1991; Sun \& Leopold, 1993; Teixeira et al., 2018).

In seeds from intermediate fruits, the maintenance of a high percentage of normal seedling formation up to the moisture level of $2.5 \%$ demonstrates that at this stage the seeds already have full tolerance to desiccation. Hong et al. (1991) observed tolerance to desiccation in seeds from Coffea arabica $\mathrm{L}$. fruits at intermediate stage of maturity.
The higher sensitivity of ripe seeds to desiccation may have resulted from their longer time of exposure to the field conditions. According to Hong \& Ellis (1996), seeds obtained in stressful environments, such as those with high temperatures, when collected after maturity, can also be sensitive to desiccation damage.

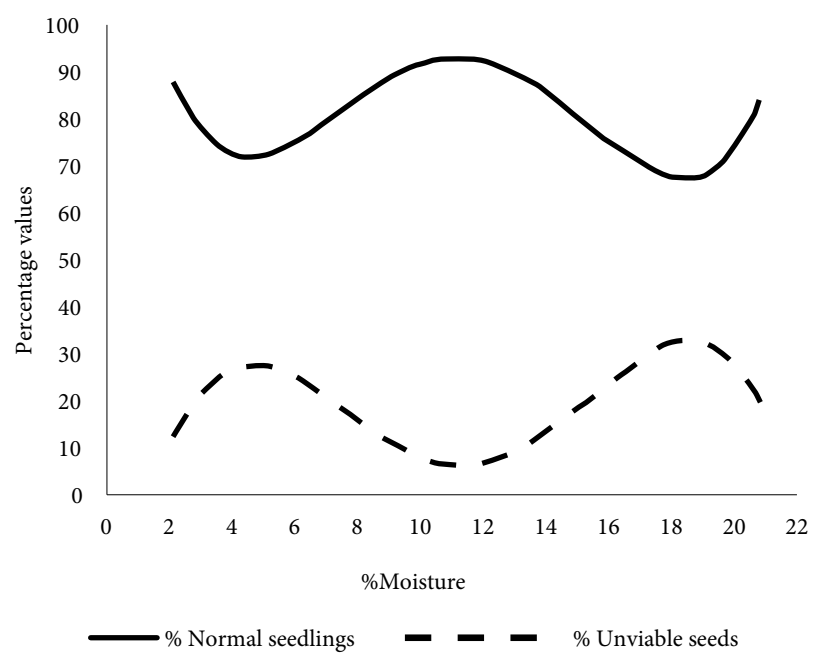

Figure 3. Percentage of normal seedlings ( $\%$ NS $=0.0106 x^{4}-0.4894 x^{3}$ $\left.+7.5368 \mathrm{x}^{2}-43.537 \mathrm{x}+156.37 ; \mathrm{R}^{2}=0.88\right)$ and $\%$ Unviable seeds $\left(\%\right.$ US $\left.=-0.0106 \mathrm{x}^{4}+0.4894 \mathrm{x}^{3}-7.5368 \mathrm{x}^{2}+43.537 \mathrm{x}-56.372 ; \mathrm{R}^{2}=0.89\right)$ as a function of the moisture content in seeds from ripe fruits of Diospyros inconstans Jacq. Where: $\mathrm{R}^{2}=$ coefficient of determination.

\section{CONCLUSIONS}

Diospyros inconstans seeds tolerate desiccation up to $2.5 \%$ moisture content. Tolerance is higher in fruit seeds with intermediate maturation than in green and ripe fruits.

\section{SUBMISSION STATUS}

Received: 29 Apr. 2020.

Accepted: 30 Jun. 2021

Associate editor: João Vicente de Figueiredo Latorraca

\section{CORRESPONDENCE TO}

\section{Edvânia da Silva Carvalho}

Universidade Federal do Reconcavo da Bahia, Rua Rui Barbosa, 710, 44380000 Cruz das Almas, BA, Brasil

\section{REFERENCES}

Akaike HA. New look at the statistic model identification. IEEE transactions on automatic control 1974; 9(6): 716-723.

Angelovici R, Galili G, Fernie AR, Fait A. Seed desiccation: a bridge between maturation and germination. Trends in Plant Science 2010, 15: 211-218. 
Angiospermas in flora do Brasil 2020 em construção. [cited 2019 dez. 13]. Available from: http://floradobrasil.jbrj.gov.br/reflora/ floradobrasil/FB128482>.

Barbedo CJ, Marcos-filho J. Tolerância à dessecação em sementes. Acta Botanica 1998, 12: 145-164.

Berjak P, Pammenter NW. From Avicennia to Zizania: Seed Recalcitrance in Perspective. Annals of Botany 2008, 101: 213-228.

Bewley JD, Nonogaki H. Seed Maturation and Germination. In: Reference Module in Life Sciences. Elsevier; 2017.

Brasil. Ministério da Agricultura e Reforma Agrária. Regras para análise de sementes. Brasília: 2009. 398p.

Buitink J, Leprince O. Letters to the twenty-first century botanist. Second series: "What is a seed? - 2. Regulation of desiccation tolerance and longevity in developing seeds: two faces of the same coin". Botany Letters 2018, 165(2): 181-185.

Callegaro RM, Araújo MM, Longhi SJ. Fitossociologia de agrupamentos em Floresta Estacional Decidual no Parque Estadual Quarta Colônia, Agudo-RS. Revista Brasileira de Ciências Agrárias 2014, 9(4): 590-598.

Cipriani VB, Lima BM, Garlet J, Ebumeo L. Seed Sanity of Diospyros Inconstans Jacq. Australian Journal of Basic and Applied Sciences 2017, 11(11): 41-47.

Colville L. Seed storage. Encyclopedia of Applied Plant Science 2017, 1(1): 335-339.

Daws MI, Garwood NC, Pritchard HW. Prediction of Desiccation Sensitivity in Seeds of Woody Species: A Probabilistic Model Based on Two Seed Traits and 104 Species. Annals of Botany 2006, 97(4): 667-674.

Ellis RH, Hong TD, Roberts EH. An Intermediate Category of Seed Storage Behaviour? I. COFFEE. Journal of Experimental Botany 1990, 41(230): 1167-1174.

Ellis RH, Hong TD, Roberts EH. An Intermediate Category of Seed Storage Behaviour? II. Effects of provenance, immaturity, and imbibition on desiccation-tolerance in coffee. Journal of Experimental Botany 1991, 42(238): 653-657.

Ellis RH, Hong TD, Roberts EH. The Development of Desiccationtolerance and Maximum Seed Quality During Seed Maturation in Six Grain Legumes. Annals of Botany 1987, 59: 23-29.

Emiliano PC, Vivanco MJF, Menezes FS. Information criteria: how do they behave in different models? Computational Statistics \& Data Analysis 2014, 69: 141-153.

Finch-Savage WE. Seed Development-Onset of Desiccation Tolerance. In: Thomas B, Murray BG, Murphy DJ. Encyclopedia of Applied Plant Science 2003: 1229-1285.

Hong TD, Ellis RH. A protocol to determine seed storage behaviour. Rome: International Plant Genetic Resources Institute, 1996. (IPGRI. Technical Bulletin, 1).
Hong TD, Ellis RH. Development of desiccation tolerance in Norway maple (Acer platanoides L. seeds during maturation drying. Seed Science Research 1992, 2(3):169-172.

Instituto Nacional de Meteorologia - INMET, 2019. [cited 2019 dez. 13]. Available from: http://www.inmet.gov.br/.

Kerbauy GB. Fisiologia vegetal. 2.ed. Rio de Janeiro: Guanabara Koogan SA, 2008.

Krzyzanowski FC, França-Neto JB. Vigor de sementes. Informativo ABRATES 2001, 11(3):81-84

Leprince O, Buitink J. Desiccation tolerance: from genomics to the field. Plant Science 2010, 179: 554-564.

Marcos-Filho J. Fisiologia de sementes de plantas cultivadas. 2 ed. Londrina: ABRATES, 2015.

Mayrinck CR, Vaz AAT, Davide CA. Classificação fisiológica de sementes florestais quanto à tolerância à dessecação e ao comportamento no armazenamento. Cerne 2016, 22(1): 85-92.

Pritchard HW, Daws MI, Fletcher BJ, Gaméné CS, Msanga HP, Omondi W. Ecological correlates of seed desiccation tolerance in tropical african dryland trees. American Journal of Botany, 2004, 91(6): 863-870.

R Development Core Team: a language and environment for statistical computing. R Foundation for Statistical Computing. Vienna: 2019.

Roberts EH. Predicting the storage life of seeds. Seed Science and Technology 1973, 1(4): 499-514.

Santos RA, Martins DL, Santos RL. Balanço hídrico e classificação climática de Köppen e Thornthwaite no município de Feira de Santana (Ba). Geo UERJ 2018, 33.

Schuwarz G. Estimating the dimensional of a model. Annals of Statistics 1978, 6(2): 461-464.

Silva BA, Nogueira JL, Vieira ESN, Panobianco M. Critérios para condução do teste de tetrazólio em sementes de araucária. Pesquisa agropecuária brasileira 2016, 51(1): 61-68.

Sousa IF, Kunzle Neto E, Muniz JÁ, Guimarães RM, Savian TV, Muniz FR. Ajuste de modelos não lineares autorregressivos na descrição da germinação se sementes de café. Ciencia Rural 2014, 44(11): 2016-2021.

Sun WO, Leopold AD. Acquisition of desiccation tolerance in soybeans. Physiology Plant, Minneapolis 1993, 87: 403-409.

Teixeira FP, Faria JMR, Pereira WVS, José AC. Maturation and Desiccation Tolerance in Seeds of Sesbania virgata (Cav.) Pers. Floresta e Ambiente 2018, 25(4): 2-9.

Tweddle JC, Dickie JB, Baskin CC, Baskin JM. Ecological aspects of seed desiccation sensitivity. Journal of Ecology 2003, 91: 294-304.

Wallnöfer B. A revision of neotropical Diospyros (Ebenaceae): part 8. Annalen des Naturhistorischen Museums Wien 2015, 117: 151-218. 